\title{
The Shifts of Themes and Rhemes in The Translation of English Political Texts into Indonesian
}

\author{
Widya Astuti \\ Department of English Applied Linguistics \\ Medan State University \\ Medan, Indonesia \\ Rahmad Husein \\ Medan State University \\ Medan, Indonesia
}

\author{
Syahron Lubis \\ North Sumatera University \\ Medan, Indonesia
}

\begin{abstract}
This study was conducted to describe The shift of themes and rhemes in The Translation of English Political Text into Indonesian. In this research, descriptive qualitative design is applied by the researcher in order to answer the questions about the types of thematic and rhematic occurred in Translation of English Political Texts into Indonesia. The data were taken from English and Indonesia political news texts of Waspada. The technique used is interactive model by Miles and Huberman (2014). This study found some enrichment with variation of theme and information structure of thematic and rhematic in English - Indonesia Waspada political text. the Based on the result of the data analysis, the findings of this study are formulated : They are three types of thematic and rhematic shift found in this research, there are Structure shift, Unit Shift, class shift and markedness shift.
\end{abstract}

Keywords: Translation Shift, Theme, Rheme

\section{INTRODUCTION}

Metafunction is a term use in functional grammar which refers to the users ways in this case human beings in using language. These ways categorized based on the purposes or goals used by the users so that producing difference meaning as well as exchanging meaning. Halliday (1994:368) divides the metafunction into three functions, interpersonal, topical and textual functions. The interpersonal function concerns with enacting and distinguishing interpersonal relations. The topical function of language is concern with the communication and interlinking of ideas; it is divided into two terms call experiental and logical function. The textual (discoursal) function is the one where by language serves as means to create texts as oppose to merely isolate and disconnect sentences. In textual function, the recognizable internal structure (theme and rheme) are use to organize human experience.

Translation is an interdisciplinary practice, particularly related to the linguistics. Research in translation studies has already focused on different linguistic features, one of the most attention grabbing branches in translation studies, is discourse analysis. One particular area of interest, in translation studies, is thematic structure. Halliday (2004) believes that textual analysis takes care of Theme-Rheme arrangement in a text. Textual analysis is the analysis of the way Theme-Rheme structures are concatenated in a text. Different researchers have selected different grammatical units to study Theme, according to their purposes. For Halliday, the basic unit for thematic analysis is the clause/sentence. The readers should have knowledge with the types and the flow in the text to know the theme and rheme in the text.

The structuring of language as a message is realized in the thematic structures of the constituent clauses of a text. Theme for Halliday (2004) is the point of departure; it is that with which the clause/sentence is concerned. So, part of the meaning of any clause/sentence lies in which elements is chosen as its Theme. He elaborates further by stating that the textual function of the clause/sentence is that of constructing the message and the Theme-Rheme structure is the basic form of the organization of the clause/sentence as the message.

Hasan (2015); Vahedifar and Koohas (2015) state that thematic structure is an important and interesting discussion in Translation study since translation is more than the mere replacement of the ST materials into the TT, theme and rheme contributed to the notion of translation. Wang (2014) adds that there are cases where the T-R structures have been shifted to $\mathrm{R}-\mathrm{T}$ and moreover the translator must make sure that the thematic patterns contribute to the cohesion and coherence of the target language text and does not distort the meaning of the original text. Seeing how important thematic structure to form the elements in delivering a message that is worth. The political news of Waspada newspaper is chosen. The English news is as the Source Text while Indonesia news is as the Target Text. The researcher in the present study attempts to contrast two languages' thematic structures (English and Indonesia) in Waspada newspaper to find out the similarities and differences between them. 
Here, the researcher found that the different information contained in both English and Indonesian Political News of Waspada influenced by the structure of theme and rheme constructed. The English news version (SL) is taken from BBC and it is published on November, $8^{\text {th }} 2017$ There are unacceptable forms according to Indonesia (TL). Based on the observation, the preliminary data showed that:

(SL) the arrest of dozens of Saudi royal figure, minister and businessman is just the start of an anticorruption drive, the attorney general says.

(TL) Gerakan antikorupsi di Arab Saudi tidak berakhir dengan penangkapan 11 Pangeran, empat menteri and puluhan mantan menteri.

Based on the data above it is found that: There is a shift of theme and rheme occurred which Theme in SL such as: in (a) "the arrest of dozens of Saudi royal figure, minister and businessman", while Theme in TL is "Gerakan anti korupsi di Arab Saudi". It is called as structure Shift which the Theme in SL becomes the Rheme in TL while Rheme in SL becomes Theme in TL

Considering the researcher's preliminary data, it is needed to conduct more research toward English and Indonesia political news of Waspada newspaper. Moreover, The problems of the study are formulated: "What types of thematic and rhematic shifts are applied in translation of English political texts into Indonesian?"

\section{LiterATURE REVIEW}

\section{a. Theme}

Halliday (2004) states that the theme is functionally occupied by the first element of the transitivity system of clause. Theme can be divided into some categories. They are ideational, Textual and interpersonal. The ideational or topical theme is usually but not always the first nominal group in the clause. Topical theme may be also be nominal group complexes, adverbial groups, prepositional phrases or embedded clauses. The element of textual Theme include conjunctions, relatives, conjunctivas and continuities. Interpersonal theme covers one or more of elements. It covers finite, question word, vocative and adjunct. Furthermore, finite shows that the clause is as an interrogative. Interrogative marker is unmarked as yes/no or finite question like is, am, are, was, were, did, have, has, shall, should, would, could, can, will, may, might.

The theme can be simple and multiple theme. Simple theme is one element of the clause function as the theme (Saragih, 2006: 112). It is clear that the function of the element in the theme is not more than one. Moreover, the theme in a simple sentence may be simple or complex. In addition, a simple theme is coded by one element of the clause. It means that one element function of the clause as the representation of experience is placed by word, group or clause. This simple theme is also called topical theme.

\section{b. Rheme}

The point after theme is necessary to be discussed. It means that after knowing thme as the first element of the clause, the Rheme is the element after the theme. Rheme is encoded as reminder of the clause. According to Saragih (2006:107) Rheme is element of the clause after Theme, in the other words, in case theme is one unit of experience, next element of the clause is rheme. Rheme follows the Theme: the presentation removes after the point of departure. A clause as message is analyzed by the theme. Theme is with which the clause is concerned and Rheme is the part where the Theme is developed.

\section{c. Shift in Translation}

Catford (1978) divides the shift in translation into two major types, level/rank shift and category shift. Category shift refers to departures from formal correspondence in translation. What is meant by formal correspondence is any grammatical categoryin the target language which can be said to occupy the same position in the system of the target language as the given source language category in the source language system (Machali, 1998: 13). The category shift is divided again into structure shifts, class shifts, unit shift, and intra-system shifts. Structure shift is the changing of words sequence in a sentence.

\section{RESEARCH METHOD}

In this research, descriptive qualitative design was applied by the researcher in order to answer the research problem. The data were taken from English and Indonesia political news texts of Waspada. The data of this study were the clauses of English - Indonesia Political texts of Waspada. The English news which is Waspada translated into Indonesian and published were taken from Al-Jazeera, Gulf News, BBC, Daily Mail, Press Trust of India and Reuters. There are five political texts in the form of English as the SL and Indonesia as TL. This choice was aimed to make the research efficient and practical. The unit of analysis is all the clauses of both English and Indonesia Political Texts of Waspada. The clauses are chosen by considering the theory of theme and rheme by Halliday. The sources of the data of this research were both version of English and Indonesia political text of Waspada.

\section{FINDINGS AND Discussions}

\section{A. Findings}

In analyzing the data, the technique used interactive model by Miles, Huberman and Saldana (2014). They state that there were three steps which were used to analyze the data, namely: data condensation, data display and drawing conclusion or verification

\section{Data Condensation}


Data Condensation is aimed at the process of raw data that appear in the written up field notes in order to be analyzed. The process can be in the form of selecting, focusing, simplifying, abstracting and transforming.

a. Selecting

In data condensation, the first step was data selection, the data were selected to find out the thematic and rhematic shifts applied in translation of waspada's political news from English into Indonesia.

b. focusing

Focusing means to pay attention to the suitable data. In this research the researcher only paid or chose the suitable data for analyzing specially on the clause that containing theme and rheme in political text of waspada newspaper in both English and Indonesia.

c. Simplifying

The third is to simplify the data by making them easier to understand. in taking some data and giving them some code

d. Abstracting

The fourth is to abstracting the data analysis was abstracted by describing in the tabulation and together with the research findings in this research.

e. Transforming.

The last step in data condensation was transforming, the researcher transformed the data by making the percentage of all data to make the data readable. in other words, it is presented in the form of table and they could be seen in the following table :

TABLE1 Transforming the data

\begin{tabular}{llrc}
\hline NO & types of shift & $\begin{array}{l}\text { Number } \\
\text { data }\end{array}$ & of \\
\hline 1 & Structural Shift & 23 & 39 \\
2 & Unit Shift & 17 & 29 \\
3 & Class Shift & 14 & 24 \\
4 & Markedness & 5 & 8 \\
& shift & & 100 \\
& Total & 59 & \\
\hline
\end{tabular}

\section{Data Display}

In data display, the data were organized. The organization was explored and described in detail description in order to be easier to draw the conclusion and also let the reader know the types of thematic and rhematic shifts in translation of English political texts into Indonesian in Waspada.

\section{Drawing Conclusion}

In the last step, drawing conclusion, the data were interpreted and draw a meaning from data display. Data display and conclusion drawing step could be discussed deeply to answer the research problem. in order to answer the research problem, conclusion was they are four types of thematic and rhematic shift found in this research, there are Structure shift, Unit shift, class shift and Markedness shift. They are 17 data for Structure shift or $29 \%, 23$ data for Unit shift or $39 \%, 14$ data for Class shift or $24 \%$ and 5 data for Markedness shift or $8 \%$

\section{B. Discussions}

Based on the data above, there are some thematic and rhematic shifts of English - Indonesia translation in Waspada political texts. The discussion of each Translation Shifts was follow:

\section{Structural shift}

A structure shift involves a change in grammatical structure of Theme and Rheme between source text (SL) and Target text (TL). It was considered structure shift as the most frequent type of shift that may occur in all rank. Whenever translation takes place between two languages of different classes, a structure shift occurred.

\section{Unit/rank shift}

Unit shift occurred when translation equivalent of a source language unit at one rank in is a unit at a different rank in the target language. In this case, the unit/ranks shift includes the shift of Simple Theme in Source language became Multiple Theme in Target language or Multiple Theme in Source language became Simple Theme in Target language.

\section{Class Shift}

Class shift occurred when the translation equivalence of an SL item is a member of a different class in TL. it change a word class.

\section{Markedness Shift}

Markedness shift occurred when the translation equivalent of a source language in this case, the theme was indicated as marked theme while it was translated differently in the target language became unmarked theme and vise verse.

\section{CONCLUSION}

This study concerned on the shifts of the thematic and rhematic in the translation of English political texts into Indonesian. After analyzing the shift of Theme and rheme in English and Indonesia of waspada political texts, it was found: There are four types of shift of Thematic and Rhematic used in both English and Indonesia Political texs; they are 17 data for Structure shift or $29 \%, 23$ data for Unit shift or 39\%, 14 data for Class shift or $24 \%$ and 5 data for Markedness shift or $8 \%$.

\section{REFERENCES}

[1] Halliday, M.A.K. (1994). An Introduction to Functional Grammar (2 ed.). London: Edward Arnold

[2] Halliday, M.A.K. (1994). An Introduction to functional grammar (2 ed.). London: Edward Arnold 
[3] Halliday, M.A.K., \& Matthiesssen.Ch. (2004), An Introduction to Functional Grammar (3 ed.). London: Edward Arnold

[4] Kalantari, afsaneh (2013). Assessment of Marked Thematic Structures in The Two persian translations of "the sound and the fury". Journal of Translation. vol.4. No. 26-2013

[5] Mardani Tooba (2016) Thematic Structure: A Study on English and Persian. Journal of Translation. Vol.2. No.2-2016

[6] M. Manfredi. (2014)Translating Text and Context: Translation Studies and Systemic Functional Linguistics. Vol. II From Theory to Practice. Bologna: Centro di Studi Linguistico-Culturali (CeSLiC).

[7] Newmark, Peter (1981). Approach to The Translation. London : Oxford Press.Newmark, Peter. (1988). A Textbook of Translation. London: Prentice Hall

[8] Nida, E. A.(1975).Language Structure and Translation. California. Standford University Press (IJSBAR) (2017) Volume 35, No 2, pp 85101
[9] Sarcinelli, U.1998.Politikvermittlung und Demokratie in der Mediengesellschaft [Politics and Democracy Seen through the Media].Bonn: BpB.

[10] Sariasih, Wiwit and prof. Dr. M.zaim, m.hum.( 2015) Students' Textual Equivalence in translating Informative text from indonesian into english (a study of the third year students of stkip pgri sumbar). Journal English Language Teaching (ELT). Volume 1

[11] Wang, Bo (2014). Theme In Translation: A Systemic Functional Linguistic Perspective. International Journal of Comparative Literature \& Translation Studies. Vol. 2 No. 4

[12] Wang, Fang(2014). The Application of Thematic Theory in Translation. Theory and Practice in Language Studies. Journal of Linguistics. Vol. 4, No. 4, pp. 778-785

[13] Yan, F. et all (1995) On Subject and Theme a Discourse Functional Perspective. Philadelphia: John Benjamin Publishing 